by the society, the association could then go on at the earliest possible date and reorganize the profession of the state in the different counties as the recognized state body.

At tlis point a member of the committee (I think Dr. Jacobi) made the statement that the committee of the society did not desire the association to stand still, but would be pleased to have them go on and organize the profession of the state without reference whatever to the negotiations going on.

As to the society, I summed up the propositions as made above by Dr. Elsner as the status of that committee.

I also said that it seened to me the only hope of the union of the two state bodies this year was to be accomplished on the following plan: That the committee of the society should make its report to the Medical Society of the State of New York at its January meeting and ask for further time to consider the propositions of the association. That inasmuch as the committee had unanimously agreed not to adopt the Constitution and By-laws of the American Medical Association now or as long as the Code of Ethics existed, that if at New Orleans the revised code was adopted and was acceptable to them, that they could then adopt the Constitution and By-laws and with it the revised code. That they could perhaps make provisions at the meeting of their society in January whereby an official body or committee could then accept, with power to act, the completed report of the committee for amalgamation of the two state bodies. That this act would make the committee of the association active and that together with the committee of the society they could then go on and secure a charter during this year.

This is a statement of the status of affairs in New York State made by an unprejudiced outsider and by one who has been and is most anxious that the profession of the Empire State should be united in one body representing the whole profession of the state in the American Medical Association.

The American Medical Association is most anxions to have the good men of the profession everywhere in its membership. And I want to repeat that no target is made of the members of the Medical Society of the State of New York. It is simply a question of adjustment of the differences between the members of the profession in New York and that they must themselves settle.

I am sure you and every other member of the Medical Society of the State of New York will find that the great body of members of the American Medical Association are desirous of having you back as members and that we are willing and desirous of helping you as far as we can. But the members of the Medical Society of the State of New York must come to the American Medical Association, and should not for a moment believe that the American Medical Association will go to them.

In conclusion it must be distinctly understood that the New York State Medical Association is the only affiliated state body in New York, and as such, the only one that the officers of the American Medical Association can recognize.

Believe me, Very sincerely yours,

Frank Billings,

President of the American Hedical Association.

\section{A Side Light on Ethics.}

Phoevix, ARiz., Jan. 17, 1903.

To the Editor:-Referring to the communication of $\mathrm{Dr}$. Gillmore in The Journal, January 3, "A Side Light on Ethics," I would like to say that the Eminent Consultant is not only responsible for the "bulldog tendency" of to-day, but also for the increase of the horde of medical Arabs who, finding it difficult to be honest with the profession or public, and live, scour the deserts and cities, seeking whom they may devour.

The Eminent Consultant of the species described by Dr. Gillmore is a reproach to the profession, and does more to bring discredit on the profession and break up professional unity, nullify professional organizations and destroy charity than do the fakers and medical parasites.

I would submit as a remedy for this disease one which. though it may seem heroic and in itself subversive of some of the tenets of the Code it is intended to preserve, at the same time might prove curative. Perilous diseases sometimes require heroic remedies, and a rule of conduct was never made that was intended to shield or protect the guilty.

The remedy that I would suggest is publicity, at least among properly constituted authorities. Neither the public nor the profession as a whole are so strabismic but that they are able to view things in their proper proportions if given a fair chance. The trouble is the medical code is so interwoven with mysteries of "Thou shalt not," and "Under my grace and guidance thou mayest," that no wonder the tender shoots in the medical profession are apt to become dwarfed and stunted.

The injury done Dr. Gillmore in a case cited might be reckuned from the commercial standpoint in the hundreds and thousands, but he has no recourse in the medical courts of law at present constituted.

There is an eminent surgeon living to-day in one of the principal cities of the country who outdoes Dr. Gillmore's Eminent Consultant. The case was this: A reputable physician, graduate of one of the best schools in the country, and who had, at the cost of the usual amount of time and hard work, fitted herself for the practice of surgery, came to the city in which the Eminent Consultant was a resident and practitioner. Being a stranger, Dr. Brown (this is an ex-parte statement) introduced herself and presented her credentials to the Eminent Consultant and asked him if he would accord her the grace of his presence, advice and assistance in a surgical procedure on a private patient of her's, the operation to be performed in one of the leading hospitals of the eity. The Eminent Consultant, Br. Black, consented to furnish all these elements of grace with the following proviso: Dr. Brown was to do the operation, assuming all the responsibility that goes with it, but in the case-book the record should read Drs. Black and Brown, and Dr. Black was to pocket two-thirds of the fee.

If this were not related by one credible witness, one of the parties in the case, it would hardly be believable. Jeaving out of consideration the matter of professional ethics and placing the case on the basis of ordinary commercial or business ethics, one would feel that a man who would treat a woman in that manner was hardly deserving of respect, much less of retaining his exalted position in the local profession. In this case Dr. Brown was helpless, and the operation was concluded on the terms proposed.

A friend of mine who was making a specialty of abdominal surgery in a small town neighboring Philadelphia, called in an Eminent Specialist residing in the latter city to consult with him in a desperate case, which proved to be general puerperal peritonitis with free pus throughout the abdominal cavity. The Eminent Consultant, after admitting to a member of the patient's family that my friend was properly qualified to perform such surgical procedure as the case might require, came down to the consultation armed with full paraphernalia for performance of same and with intent to do the operation. IVhen informed that he had simply been called at the family's request as consultant he went off in a huff, and afterwards, as I have been informed, said some very harsh things reflecting on the ability of the operator and in regard to the termination of the case, which was death. W. H. Burr.

\section{State Boards of Registration.}

Rhode Island.-Dr. Gardner T. Swarts, secretary, reports the Rhode Island State Board of Health to have held an examination at Providence, Jan. 2 and 3, 1903, in which the number of subjects was 7 ; questions, 70 ; percentage required to pass, 75 ; written examination; number examined, 9 ; passed, 7 ; failed, 2.

\section{Candi- Sch. of \\ date. Pract.}

194 R.

R.
$R$.
$R$.
$R$.
$R$.
R.
R.

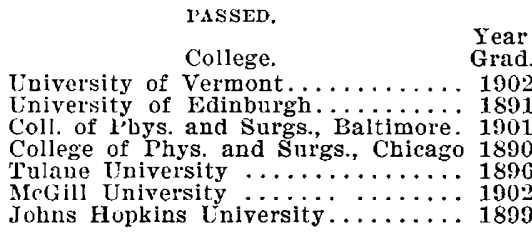

FAILED.

$\begin{array}{ll}195 & \text { R. Dartmouth Medical College....... } 1900 \\ 197 & \text { II. New York Homeopathic Med. College } 1881\end{array}$
Per

79.0 